\title{
The Basal Conglomerate of the Capacete Formation (Mata da Corda Group) and its Relation to Diamond Distributions in Coromandel, Minas Gerais State, Brazil O conglomerado basal da Formação Capacete (Grupo Mata da Corda) e sua relação com as distribuições de diamantes em Coromandel, Minas Gerais, Brasil
}

\author{
Augusto Fonseca Fernandes ${ }^{1 *}$, Joachim Karfunkel ${ }^{1}$, Donald Brunton Hoover ${ }^{2}$, \\ Patrícia Barbosa de Albuquerque Sgarbi ${ }^{1}$, Geraldo Norberto Chaves Sgarbi ${ }^{1}$, \\ Gustavo Diniz Oliveira ${ }^{3}$, Joanna Correia de Souza Pereira Gomes ${ }^{1}$, Klaus Kambrock ${ }^{4}$
}

\begin{abstract}
The diamond bearing district of Coromandel is located in the northwestern part of Minas Gerais, within the Alto Paranaíba Arch, famous for the discovery of most of Brazil's large diamonds above 100 ct. Detailed mapping, aimed at characterizing the Mata da Corda Group of Upper Cretaceous age of Coromandel, has been carried out. This Group was divided into the Patos Formation, composed of kimberlitic and kamafugitic rocks, and the Capacete Formation, presented by conglomerates, pyroclastic rocks, arenite and tuffs. Exposures of the latter Formation have been studied in detail at the small abandoned mine called Canastrel, as well as in the headwater of Santo Antônio do Bonito River. The results have been compared to studies of the kimberlite bodies in the nearby Douradinho River. Kimberlite indicator minerals from these localities show the same compositional trend. Moreover, in the basal conglomerate of the Garimpo Canastrel two diamonds diamonds have been recovered and described. The Garimpo Wilson, situated in the headwater of the river Santo Antônio do Bonito in paleo-alluvium, is composed of material exclusively derived from the erosion of the Capacete Formation and Precambrian (sterile) Canastra quartzites and schists. These detailed investigations suggest that the basal conglomerates of the Capacete Formation represent the main source rock of the alluvial diamond deposits in the Coromandel region.

KEYWORDS: Upper Cretaceous; conglomerate; diamond; alluvium.
\end{abstract}

\begin{abstract}
RESUMO: Conhecida como "Terra do Diamante", o município de Coromandel está localizado no nordeste de Minas Gerais, no Arco do Alto Parnaíba, famoso pela descoberta da maioria dos diamantes brasileiros acima de $100 \mathrm{ct}$. Foi feito um mapeamento detalhado da região, visando caracterizar o Grupo Mata da Corda (Cretáceo Superior) de Coromandel. Este Grupo foi dividido entre a Formação Patos, composta de rochas kamafugiticas e kimberlíticas, e a Formação Capacete, que apresenta rochas piroclásticas, arenito e tufos. Desta última, foram detalhadamente estudadas exposiçóes encontradas na pequena mina abandonada de Canastrel, assim como na nascente do rio Santo Antônio do Bonito. Os resultados foram comparados a estudos de outros corpos kimberliticos do entorno do rio Douradinho. Minerais indicadores de kimberlita dessas regiöes mostram a mesma tendência composicional. Além disso, no conglomerado basal do Garimpo Canastrel, foram recuperados e descritos três diamantes. O Garimpo Wilson, situado no paleoaluvião da nascente do rio Santo Antônio do Bonito, é composto de material derivado exclusivamente da erosáo da Formaçáo Capacete e de quartzitos do Grupo Canastra existos Pré-cambrianos (estéreis). Estas investigaçōes detalhadas sugerem que os conglomerados basais da Formaçäo Capacete representam a principal rocha de origem dos depósitos de diamantes aluviais na região de Coromandel.
\end{abstract}

PALAVRAS-CHAVE:Cretáceo Superior; conglomerado; diamante; aluviāo.

\footnotetext{
${ }^{1}$ Programa de Pós-graduação, Instituto de Geociências, Universidade Federal de Minas Gerais - UFMG, Belo Horizonte (MG), Brazil. E-mail: augffs@gmail.com; jkarfunkel@yahoo.com; psgarbi@ufmg.br; gncsgarbi@gmail.com; joanna.geologia@gmail.com

${ }^{2}$ Private consultant, Springfield (MO), USA.E-mail: dbhoover2@att.net

${ }^{3}$ Votorantim Metais, Vazante (MG), Brazil.E-mail: gustavo.oliveira.go1@vmetais.com.br

${ }^{4}$ Instituto de Ciências Exatas, Universidade Federal de Minas Gerais - UFMG, Belo Horizonte (MG), Brazil. E-mail: klaus@fisica.ufmg.br

*Corresponding author

Manuscrito ID 29939. Recebido em: 24/03/2013. Aprovado em: 26/02/2014
} 


\section{INDRODUCTION}

Since the beginning of the "diamond rush" to the Coromandel region in the second half of the 18th century (Barbosa 1991), this region stood out in the Brazilian geological scene as the only periodic producer of large diamonds (> $100 \mathrm{ct}$ ) in the country, mainly in the 20th century (e.g. Reis 1959; Barbosa 1991; Liccardo \& Svisero 2005; Hoover \& Karfunkel 2009). The diamonds are explored from gravel horizons of Pleistocene to Holocene age by garimpeiros in the Santo Antônio do Bonito, Santo Inácio, Douradinho, Dourados and Santo Antônio das Minas Vermelhas rivers.

Despite broad prospecting programs run by major diamond companies over many decades and the discovery of hundreds of sterile or non-economic kimberlites and similar intrusions, to date there is no consensus about the source and distribution of these gems. During the last years many authors discussed two hypotheses to explain such an enigma.

The first hypothesis, which was introduced by Tompkins \& Gonzaga (1989) and Gonzaga et al. (1994), suggests an allochthonous diamond source. Primary Precambrian diamond sources, such as kimberlites, intruded in the São Francisco Craton, and were transported by glaciers during a Proterozoic continental glaciation (Karfunkel \& Hoppe 1988), and deposited in diamictites of the Ibiá Group and Samburá Formation. They then have been reworked and concentrated locally in river gravels.

The other hypothesis suggests an autochthonous diamond source, linked probably to the various kimberlite bodies present in the region (e.g. Svisero et al. 1984, 1986; Barbosa 1991; Svisero 1992; Leonardos et al. 1996; Chaves et al. 2005; Svisero $\&$ Basei 2005). Their main arguments are the similar indicator mineral chemistry, as well as the diamond mineralogy and crystallography suggesting little transport.

Geological mapping on a scale of 1:50,000 has been carried out by Fernandes (2013), aimed at characterizing the Upper Cretaceous units in the Coromandel region, especially those of the Mata da Corda Group, and to link some of their minerals, such as the indicator minerals, to those found in many alluvial diamond garimpos of the region. As case studies an alluvial garimpo situated at the headwaters of the Santo Antônio do Bonito River, and another situated in the Mata da Corda conglomerates were chosen. The latter was of great value, because it revealed, in the geologic section, rocks of different nature, as well as facies transitions. In the lower conglomerate three diamonds were recovered and characterized. Moreover, the indicators mineral compositions have been compared to those of two small kimberlites in the nearby Douradinho River. Although the present study is a first step towards a different hypothesis concerning the source of diamonds in Coromandel, it hopes to show the relationship between alluvial diamond occurrences in the region and the Mata da Corda rocks in the study area.

\section{GEOLOGICAL SETTING}

The Coromandel diamond district in western Minas Gerais belongs geographically to the Triângulo Mineiro (Fig. 1). Geologically, it is located within the Brasilia FoldBelt (Almeida 1967, 1977) and is built up by crustal sequences, converged against the São Francisco Craton, towards the East, during the Brasiliano geotectonic cycle.

The stratigraphic units that form the Brasília Belt are represented by Meso-Neoproterozoic rocks of the Vazante, Canastra, Ibiá-, and Araxá groups. Dardenne (2000) divides the Vazante Group into seven formations, composed by carbonate and pelitic rock successions and subordinately rudaceous rocks. The Canastra Group (Barbosa et al., 1970) is composed essentially of quartzites, phyllites and schists. Pereira et al. (1994) divided the Ibiá Group into the Cubatâo Formation (diamictites of glacial origin) and the Rio Verde Formation (phyllites). Rodrigues (2008) dated detrital zircon grains, and determined maxima sedimentary ages of $1.2-0.9 \mathrm{Ga}, 1.0-0.9 \mathrm{Ga}$ and $990-640 \mathrm{Ma}$ for the Vazante, Canastra and Ibiá groups, respectively. The Araxá Group (Barbosa et al. 1970) is composed mainly by metamafic rocks, with subordinate metasedimentary rocks such as schists and quartzites (Seer \& Dardenne 2000; Seer et al. 2001). They are intruded by syn-collisional granites dated at $637 \pm 2 \mathrm{Ma}$ (Valeriano et al. 2004).

The Coromandel region is part of the Alto Paranaíba Arch (Ladeira et al. 1971), which divides the Sanfranciscana and Paraná basins (Fig. 1). The uplift of this crustal segment, followed by intrusions of alkaline rocks (e.g. Serra Negra, Catalão, and Araxá), kimberlites and kamafugites, during the Late Cretaceous was within a NW-SE-oriented narrow strip in the Proterozoic Brasilia belt. The magmatism, clearly seen on magnetometric maps (Hasui \& Haralyi 1991), has been related to the Trindade mantel plume (Gibson et al. 1995).

A consequence of this mafic magmatism was the formation of the Mata da Corda Group rocks, which occur above Precambrian sequences, separated by an angular unconformity. These rocks are widely distributed in the study area. Campos \& Dardenne (1997) and Sgarbi et al. (2001) divided the Mata da Corda Group into the Patos and Capacete formations.

The Patos Formation consists of volcanic and subvolcanic rocks with kamafugite, kimberlite and lamproite affinities as well as subordinate volcanoclastic 
rocks (Leonardos et al. 1991; Sgarbi 1991). The Capacete Formation is composed principally of volcanoclastic rocks, conglomerates and epiclastic arenites derived from the erosion of the Patos Formation. Its thickness can reach $130 \mathrm{~m}$ (Sgarbi et al. 2001), reflecting the magnitude of this Late Cretaceous volcanism. The Capacete Formation in the Sanfranciscana basin is time-correlated to the Uberaba Formation of the Paraná Basin (Sgarbi et al. 2001). The age of the Mata da Corda Group lies between 80 and $90 \mathrm{Ma}$ (Hasui \& Cordani 1968; Gibson et al. 1995; Sgarbi et al. 2000, 2004; Svisero \& Basei 2005).

\section{CHARACTERIZATION OF THE MATA DA CORDA GROUP NEAR COROMANDEL}

The rocks of the Upper Cretaceous Mata da Corda Group unconformably overlay the Meso-Neoproterozoic lithologies of Vazante, Canastra, Ibiá and Araxá groups. The Mata da Corda Group has been divided (Sgarbi et al. 2001) into the Patos and Capacete formations, as illustrated in the stratigraphic column (Fig. 2). The Patos Formation is composed of kimberlitic, kamafugitic, and similar ultramafic rocks, occasionally including

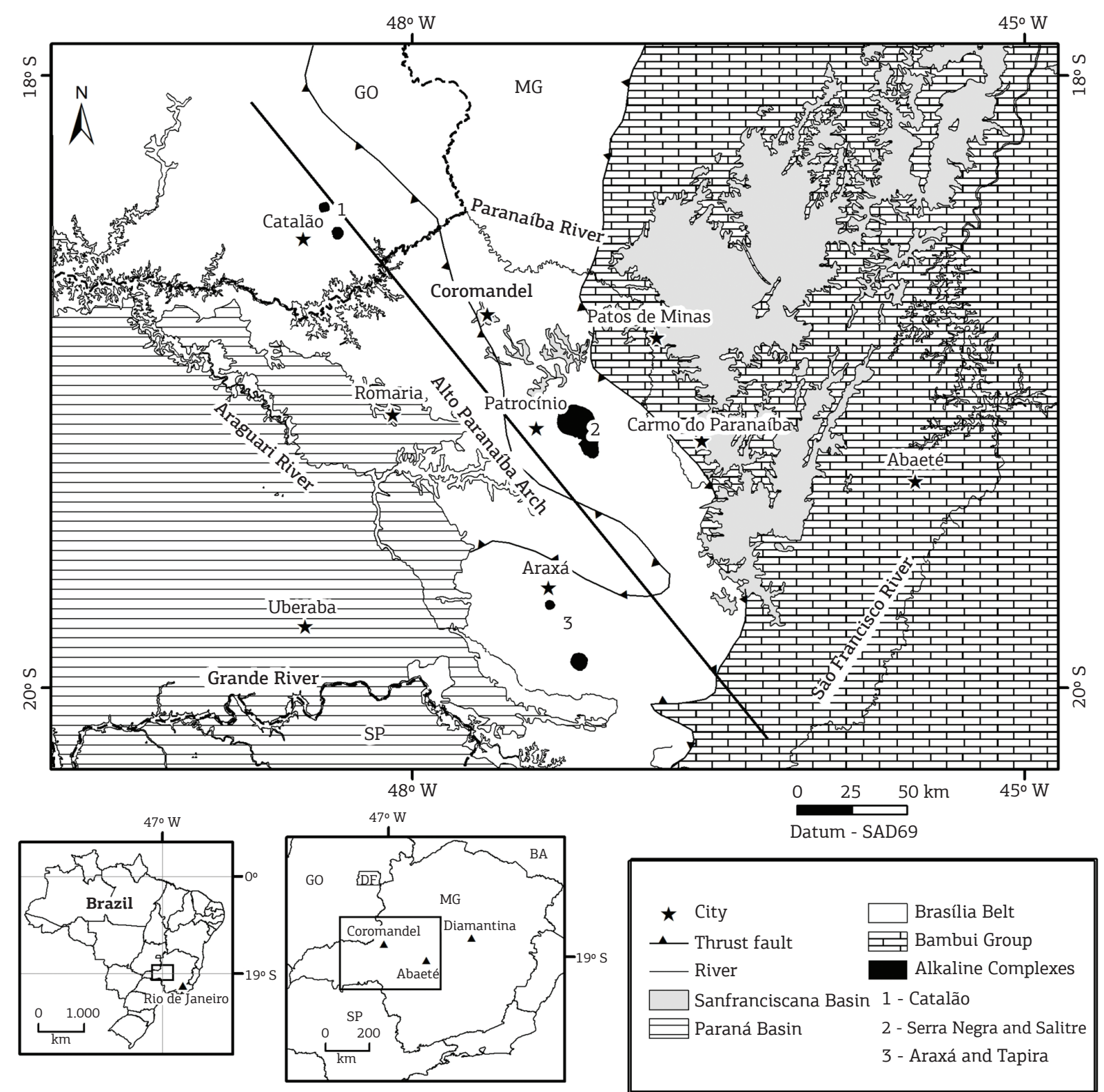

Figure 1. Geologic map of the Coromandel area, showing the Alto Paranaíba Arch, the Sanfranciscana and Paraná basins, and the major alkaline complexes (modified from Heineck et al. 2004). 
pyroclastic and sedimentary rocks as well. The Capacete Formation is composed of epiclastic and volcanoclastic rock successions that reach a thickness up to $65 \mathrm{~m}$. Laterite and lateritic soil cover the full extent of the Capacete Formation. These rocks stand out in the morphology by forming flattopped mesas as in the Serra das Mesas between Coromandel and Patrocínio (the term Capacete means helmet), typical for the Alto Paranaíba Arch region (Mata da Corda Upland), which lies between 950 and 1,000 $\mathrm{m}$ and represents the Late Tertiary Sul-Americana peneplain surface as named by King (1956).

\section{Patos Formation}

The unit is represented by volcanic and subvolcanic rocks. These occur in outcrops usually as volcanic breccia

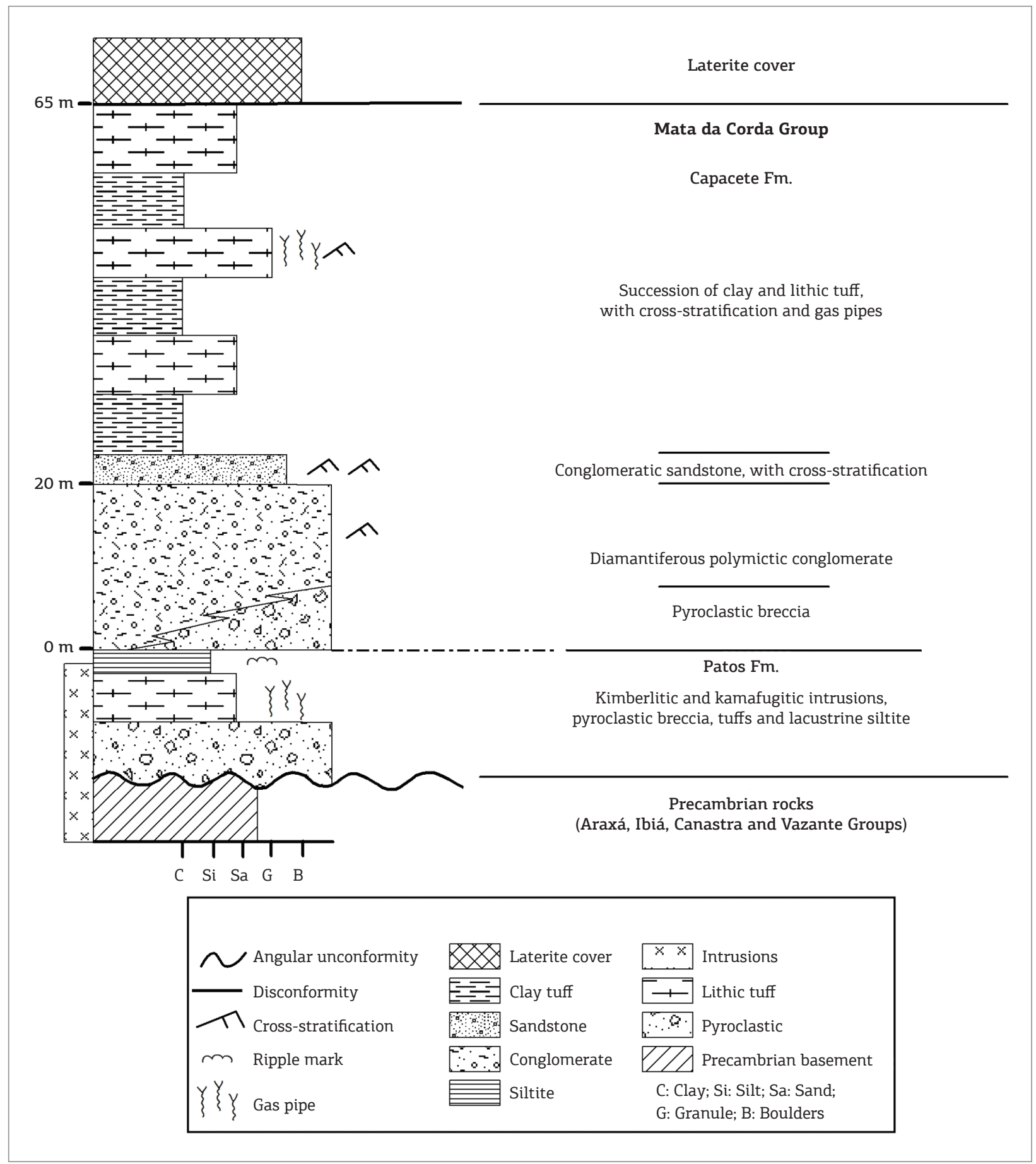

Figure 2. Stratigraphic column of Mata da Corda Group for the Coromandel region (Fernandes 2013), showing details of the Patos and Capacete formations. 
with multiple rock fragments such as quartzite, schists, phyllites, pelites, dolomites, quartz, and volcanic fragments in a clayish matrix of green, grey, yellow, beige and brown colors, depending on its weathering stage. Mantel derived macrocrystals of garnet, ilmenite, chromite, Cr-diopside and olivine occur too. The presence of pyroclastic rocks (Fig. 3A) points towards the explosive nature of some eruptions. Lacustrine siltstone rarely occurs on top of some intrusive bodies, representing Maar sediments.

\section{Capacete Formation}

The Capacete Formation is composed of volcanoclastic and rudaceous epiclastic rocks containing abundant contributions of volcanic rock fragments, derived from the Patos Formation. At the base of the Capacete Formation a polymictic conglomerate occurs, subordinately alternating with pyroclastic rocks. The conglomerate shows lateral facies transitions to lithic sandstones with cross-bedding; layers of tuffs follow on top of the sequence.

The conglomerate is matrix supported (Fig. 3B) with a maximum thickness of $15-20 \mathrm{~m}$, comprised of quartzite, ferruginous quartzite, metapelite, schist, volcanic rocks, sandstone, pelite, limestone, chert quartz and granitoid clasts. The majority of the clasts are sub-rounded; however some are well rounded or angular and their sizes vary from granule to cobbles, but pebble sizes predominate. The matrix is sandy and poorly sorted, formed mainly of quartz grains and subordinate clay and altered feldspars as kaolin. Locally, the conglomerate has a green, pelitic matrix (smectite), with some clay and rock fragments, but the total absence of quartz and the amount of volcanic rock clasts are outstanding.

Our petrographic studies show that the quartz in the quartz-rich conglomerate matrix is composed of well-rounded grains and cemented by microcrystalline silica, interpreted as diagenetic chalcedony. Plagioclase, microcline, phlogopite, pyroxene, titanite and opaque minerals (magnetite, ilmenite and perovskite) in minor quantities have also been observed. Some quartz grains show "rounded entrances" (Fig. 3C), interpreted as a consequence of corrosion processes in the magmatic milieu, which together with the other described aspects such as components of different genesis in many conglomerates leaves no doubt about the mixed character of these conglomerates and allows one to designate them as epiclastic sediments.

On top of the conglomerate a $5 \mathrm{~m}$ thick layer, composed of sandstone and some rock fragments, occurs. Sandy laminations (white, beige and grey) intercalated in this layer define a planar stratification, as well as cross-bedding with sets reaching up $0.5 \mathrm{~m}$. Isolated pebble and conglomerate levels in the middle of the cross-bedding can be observed, as shown in Fig. 3D.
A thick tuff package succeeds within the Capacete Formation sequence towards the top, reaching up $40 \mathrm{~m}$ in thickness. The high quality of the clay in this layer is exploited by the ceramic industry. The best outcrops are found in clay mine situated about $15 \mathrm{~km} \mathrm{SE}$ of Coromandel. The tuff is often silicified with geodes of microcrystalline quartz, which, under the microscope, can be classified as chalcedony. Smectite and phlogopite were also detected in petrographic studies (Fernandes 2013). Alternations between exclusively metric clay layers and clay-silt layers are observed. In the latter, cross-bedded sandy intercalations containing dispersed rock fragments also occur. Of genetic importance are opaque oxide grain levels, composed of magnetite and ilmenite, as well as vertically oriented structures filled with quartz and kaolin, interpreted as gas pipes (Fig. 3E). They represent original cavities of trapped gas formed during the rapid deposition of the sediment (Cas \& Wright 1987). All the above observations corroborate a pyroclastic origin of these rocks according to the Schmid (1981) classification.

\section{CASE STUDIES}

The first case study has been carried out at the Garimpo Canastrel, which is located within rocks of the Capacete Formation, whereas the second site is situated at an old garimpo, named Wilson, within alluvials, located at the headwaters of the Santo Antônio do Bonito river.

\section{Garimpo Canastrel (UTM Projection, Datum SAD 69, E279584/N7950829)}

This garimpo is located $25 \mathrm{~km}$ SE of Coromandel, on the NE slope of a narrow mesa, formed by Capacete Formation rocks, and overlain by a laterite crust. The range runs NNW-SSE and forms the watershed between the Rivers Santo Antônio do Bonito and Santo Inácio (Fig. 4). The garimpo, deactivated for over a decade, consists of a rectangular pit, approximately $30 \mathrm{~m}$ long by $15 \mathrm{~m}$ wide, from which around $1,000 \mathrm{~m}^{3}$ of material has been worked for diamonds.

The washed material corresponds to the basal conglomerate of the Capacete Formation, which can reach over $5 \mathrm{~m}$ in thickness. The basal contact is with the Vazante metapelites, whereas the top represents a lateritic crust of $15 \mathrm{~m}$ thickness, which hides almost all outcrops beneath the plateau. The conglomerate (Fig. 5A) is composed of rock fragments in sandy beige to brown matrix, containing secondary feldspar grains (kaolin) and microcrystalline silica. The clasts are mainly quartz, quartzites and sandstone, subordinately ferruginous quartzite, schist, phyllite, pelite, limestone, granitoid and volcanic rocks. 

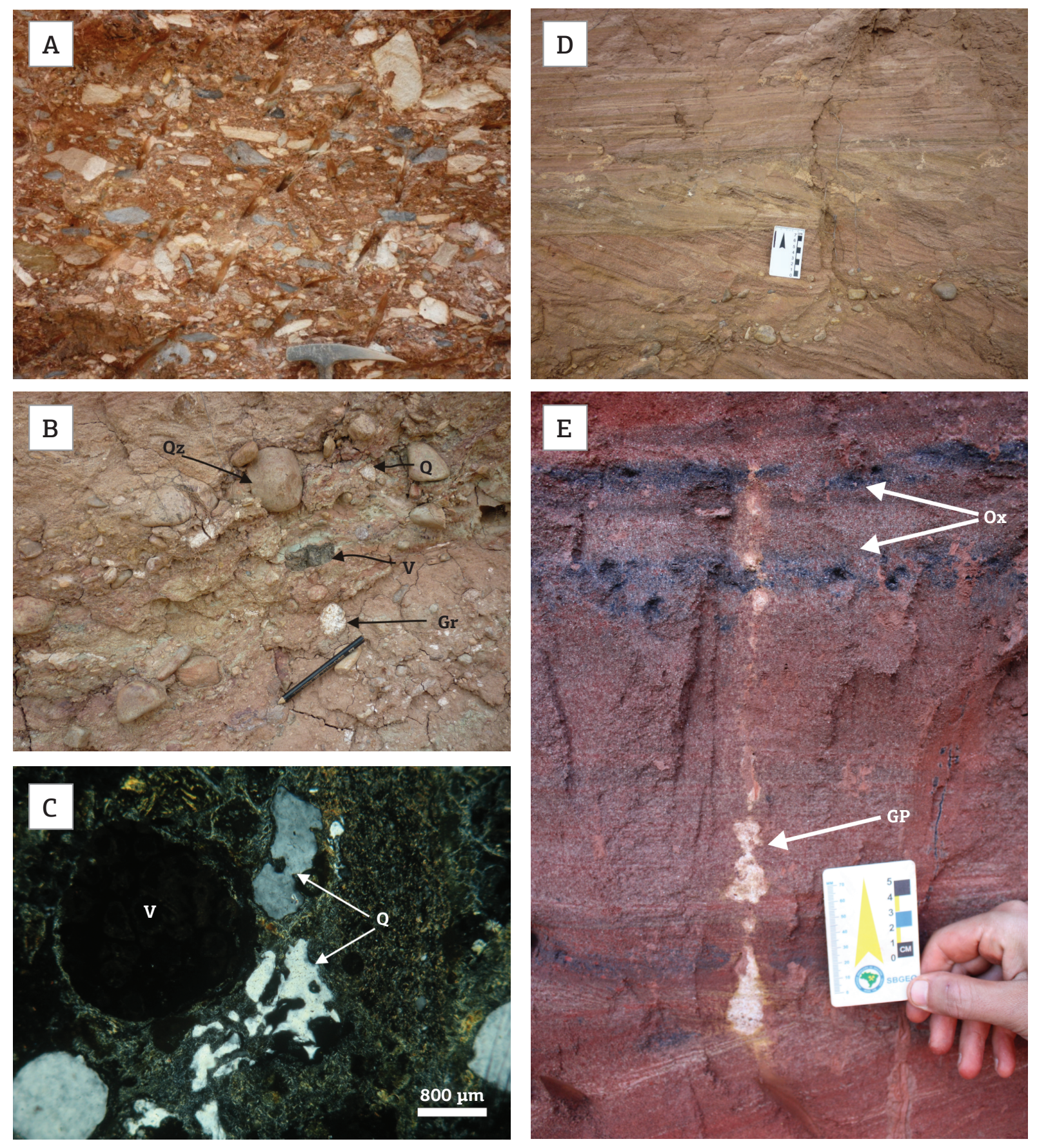

Figure 3. (A) Pyroclastic rock, interpreted as conduit breccia within the Patos Formation (UTM Sad 69, E276563/ N7948936); (B) Basal polymictic conglomerate of the Capacete Formation containing clasts of quartz (Q), quartzite (Qz), granitoide (Gr) and volcanic rocks (V), dispersed in a sandy matrix. Outcrop location: Serra da Mesa (UTM Sad 69, E273118/N7948766); (C) Photomicrography of a polymictic conglomerate from the Capacete Formation, showing quartz grains $(\mathrm{Q})$ with rounded "corrosion entrances" and clasts $(\mathrm{V})$ of volcanic rocks; (D) Cross-bedded sandstone and conglomeratic levels from the Capacete Formation (UTM Sad 69, E273138/N7948796); (E) Top layer of the Capacete Formation in a clay mine $15 \mathrm{~km}$ SE of Coromandel showing cross-bedded tuff with a white gas pipe (GP) filled with quartz and kaolin, as well as levels of oxides (Ox), identified as magnetite and ilmenite (UTM Sad 69, E276563/N7948936). 


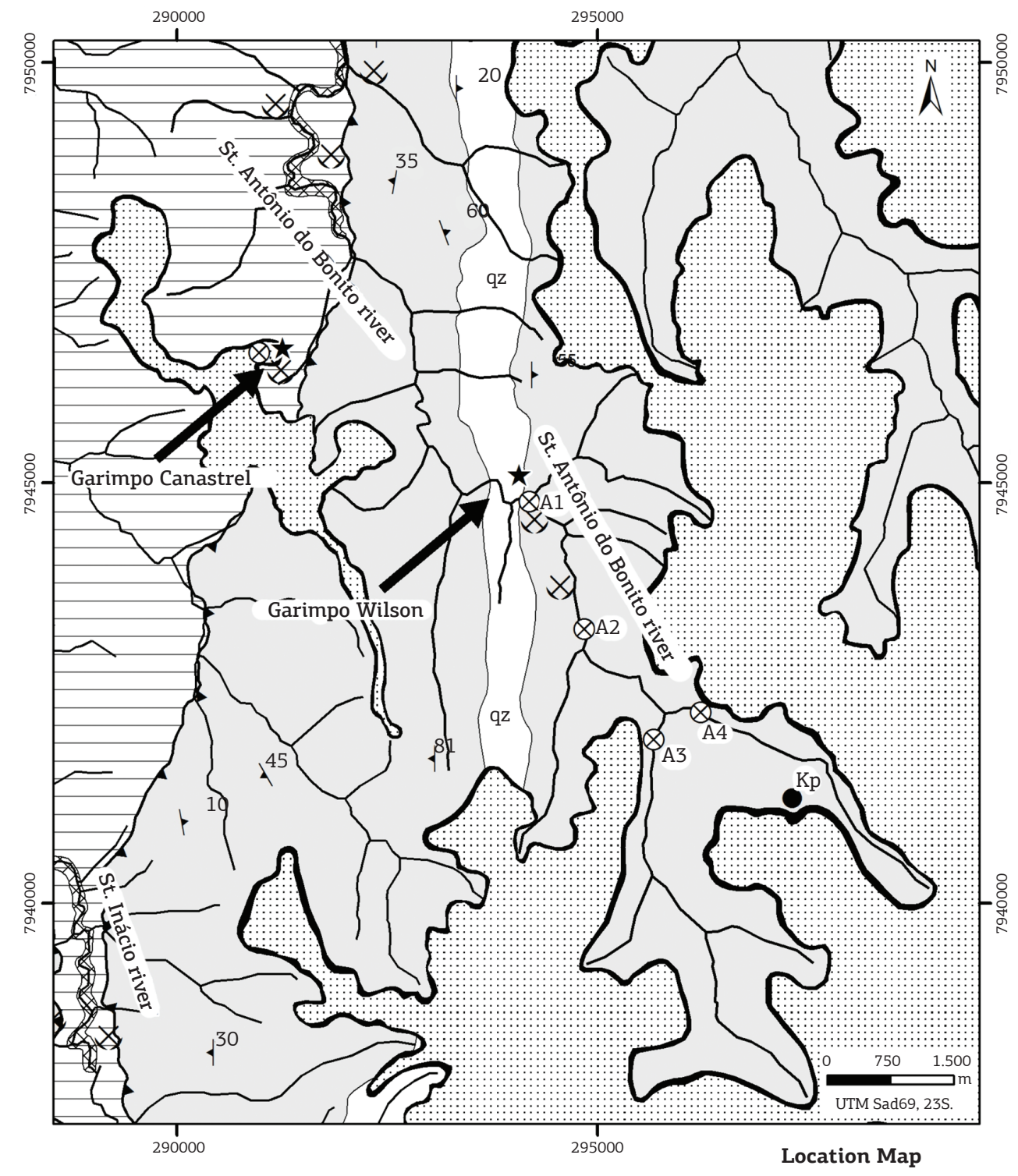

Cenozoic

Alluvial cover (sandstone and conglomerate)

Laterite cover

Cretaceous

Mata da Corda Group

Capacete Fm: pyroclastic rocks, conglomerates, sandstones and tuffs

Kp Patos Fm: Kimberlitic and kamafugitic intrusions

Meso-Neoproterozoic

Canastra Group

az Chapada dos Pilões Fm: mica schists, quartzites and phyllites (qz: quartzites). Vazante Group

$\square$ Santo Antônio do Bonito Fm: diamictite, metasiltstone and quartzite

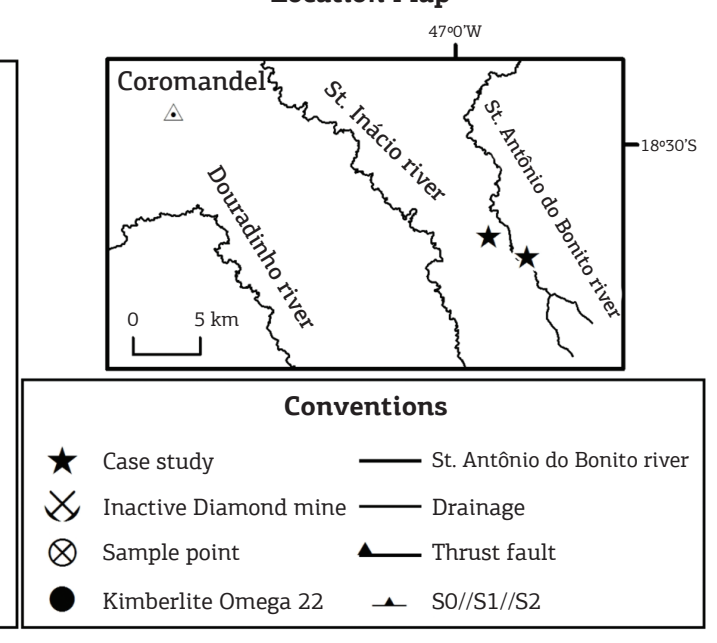

Figure 4. Detailed geological map, with the Garimpos Canastrel and Wilson, as well as the sampling points in the Santo Antônio do Bonito River. 
The authors washed 120 liters of the conglomerate and found garnet and ilmenite grains, which have been classified as indicator minerals of kimberlites (chapter on Chemistry). The garnets are red, rounded and about $3 \mathrm{~mm}$ in diameter. Scanning electron microscope (SEM) shows that the garnets exhibit a kelyphitic rim (Fig. 5B) formed during ascension within the volcanic conduit. They also show a striated surface resulted from dissolution caused by reaction with magma and, no breakages. These characteristics suggest a proximal source with a short transport for the garnet. The ilmenites are tarnished grey due to an alteration shell (leucoxene), caused during the same magmatic ascension process. Conchoidal fractures reveal a black metallic luster in the inner parts of the ilmenites.

According to the last owner of the Garimpo, Mr. Ingo Wender, three diamonds had been recovered from this garimpo during the 1990s. Two of these diamonds (Fig. 5D) are described and analyzed in detail by Karfunkel et al. (2014), who describe the larger one $(0.75 \mathrm{ct})$ as yellow and with small inclusions and the smaller one $(0.497 \mathrm{ct})$ as white. Both diamonds exhibit surface features that indicate a short transport and comparison with diamonds from the
Diamantina region (Karfunkel et al. 2001) show a different transport history.

\section{Garimpo Wilson (UTM Projection, Datum SAD 69, E291126/N7946476)}

The Garimpo Wilson is situated on the right bank of the headwaters of the Santo Antônio do Bonito River, approximately $7 \mathrm{~km}$ downstream from its two sources (Fig. 4). It lies about $27 \mathrm{~km}$ SE of Coromandel and only $3 \mathrm{~km}$ ESE of the Garimpo Canastrel. The garimpo occupies an area of $60 \mathrm{~m}$ along the stream, and $20 \mathrm{~m}$ in E-W direction. Other small pits have been observed near the stream and upwards from the main garimpo. The authors estimated that a volume of approximately $8,000 \mathrm{~m}^{3}$ of material has been washed. The extracted rock corresponds to an alluvium, consisting of a gravel layer, essentially composed of quartz and micaceous quartzite clasts (probably inherited from Canastra Gr. rocks), which vary from granule to cobble, with most of them pebble size, normally rounded, but some angular examples occur as well. In minor quantity schist, phyllite, laterite, and grains of hematite, magnetite and ilmenite occur. The matrix is reddish brown to beige, with a clay to sandy composition.
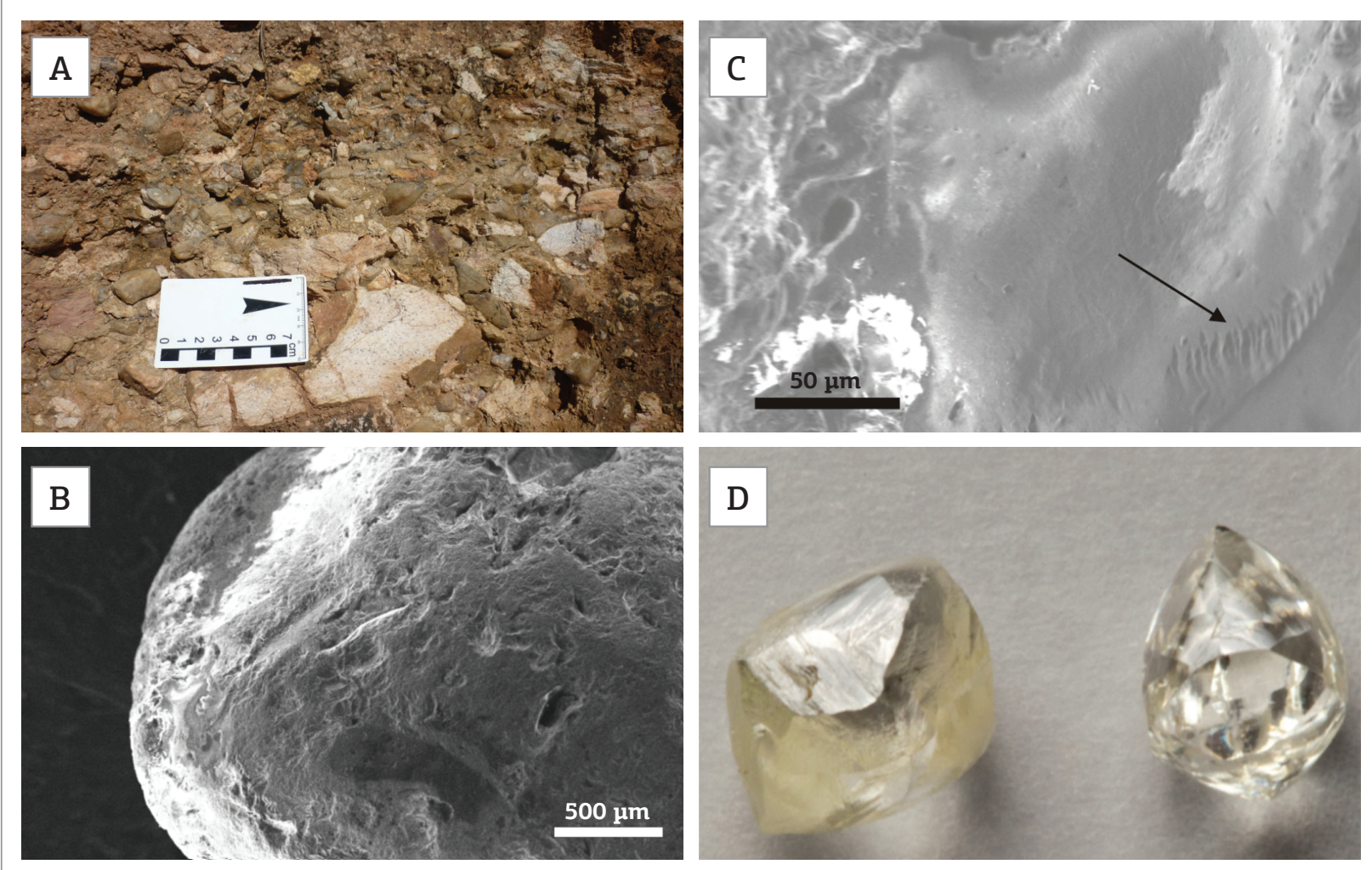

Figure 5. (A) Diamondiferous polymictic conglomerate of the Garimpo Canastrel worked within the Capacete Formation (UTM Sad 69, E279584/N7950829); (B) Photomicrography showing the kelyphite rim of garnets from the Garimpo Canastrel; (C) Detail (SEM) of a garnet showing striated surface resulting from dissolution, caused by the magma reaction; (D) Two diamonds, $0.75 \mathrm{ct}$ and $0.497 \mathrm{ct}$, from the Garimpo Canastrel, described and analysed by Karfunkel et al. (2014). 
This gravel layer is on average $0.5 \mathrm{~m}$ thick, but can reach a maximum of $1 \mathrm{~m}$, and is covered by colluvium up to $8 \mathrm{~m}$ in thickness, but usually not passing $4 \mathrm{~m}$ in thickness.

The authors performed a follow-up campaign with four sampling sites of approximately 100 liters per site (A1 to A4 in Fig. 4) along the riverbed. At sampling sites A4 and A3 no possible kimberlitic indicator minerals have been found; only hematite, magnetite and limonitic pyrite were found. At sampling sites A2 and A1 ilmenite grains have been recovered in abundance (compare chemical composition in the next section).

\section{CHEMICAL ANALYSES OF INDICATOR MINERALS}

Analyses to compare the chemical composition of indicator minerals (garnet and ilmenite), from three different kinds of source materials, have been carried out. These materials were conglomerate from Garimpo Canastrel, alluvium from Garimpo Wilson and two kimberlites (Douradinho 10 and França 1) located in the nearby Douradinho river basin (UTM, Sad 69, E266888/N7948592 and E287109/ N7932456 respectively). Pyrope garnets and magnesian ilmenites are considered as excellent indicator minerals of kimberlites and, consequently, used in diamond prospection, as shown by pioneer studies of Mitchell (1973) and Gurney (1984).

Five pyrope garnet grains, as well as five ilmenites, were analyzed (Tabs. 1 and 2), with 10 point analyses in each section of a grain. All analyses were performed at the Micro Analyses Laboratory of the Instituto de Ciências Exatas, at the Universidade Federal de Minas Gerais, by using an electron microprobe (EMP) (model JCXA-8900R; JEOL), with an energy-dispersive detector NORAN. Related composition analyses (EDS) as well as quantitative analyses (WDS) were carried out.

The analyzed grains were two garnets and one ilmenite from Garimpo Canastrel, two ilmenites from Garimpo Wilson, and three garnets, as well as two ilmenites from the above mentioned kimberlites. The garnets were classified using the $\mathrm{CaOxCr}_{2} \mathrm{O}_{3}$ diagram proposed by Grütter et al. (2004). They have $\mathrm{CaO}$ values of 3.84 to $4.83 \%$ and $\mathrm{Cr}_{2} \mathrm{O}_{3}$ values of 0.47 to $3.19 \%$, and thus can be classified as pyroxenitic garnets of the type G4 and G5 (Fig. 6A). These garnets are associated with diamond bearing peridotites and eclogites. The values for the ilmenite grains show high magnesium content between 7.58 and $12.09 \%$, indicating that they are magnesian ilmenites. According to the $\mathrm{MgOxTiO}_{2}$ diagram proposed by Wyatt et al. (2004), all ilmenite grains are of kimberlitic origin (Fig. 6B).

\section{DISCUSSION}

The basal polymictic conglomerate of the Capacete Formation shows abundant contributions of volcanic and volcaniclastic rocks in its composition, as already indicated by several authors (e.g. Sgarbi et al. 2001). This evidence combined with many other features such as rounding and

Table 1. Composition of the garnets from the sampling sites in the Garimpo Canastrel, as well as from the kimberlites Douradinho 10 and França 1 (EMP analyses)

\begin{tabular}{l|c|c|c|c|c|c|c|c|c|c|c}
\hline $\mathbf{n}^{\mathbf{0}}$ & Sample & $\mathrm{SiO}_{2}$ & $\mathbf{F e O}$ & $\mathbf{M g O}$ & $\mathbf{C a O}$ & $\mathbf{C r}_{2} \mathbf{O}_{3}$ & $\mathbf{A l}_{2} \mathbf{O}_{3}$ & $\mathbf{N a}_{2} \mathbf{O}$ & $\mathbf{T i O}_{2}$ & $\mathbf{M n O}$ & $\mathbf{T o t a l}$ \\
\hline GC-1 & Conglomerate (Canastrel) & 40.63 & 8.98 & 20.24 & 4.09 & 2.14 & 21.98 & 0.06 & 0.33 & 0.43 & 98.88 \\
\hline GC-2 & Conglomerate (Canastrel) & 39.94 & 9.09 & 20.90 & 3.84 & 0.47 & 23.55 & 0.03 & 0.12 & 0.30 & 98.24 \\
\hline GK-1 & Kimberlite Douradinho 10 & 41.15 & 8.75 & 19.82 & 4.63 & 2.4 & 22.32 & 0.05 & 0.08 & 0.44 & 99.64 \\
\hline GK-2 & Kimberlite Douradinho 10 & 41.14 & 8.63 & 19.56 & 4.83 & 3.19 & 21.76 & 0.04 & 0.05 & 0.45 & 99.65 \\
\hline GK-3 & Kimberlite França 1 & 40.53 & 9.32 & 20.35 & 3.84 & 1.68 & 22.45 & 0.07 & 0.31 & 0.41 & 98.96 \\
\hline
\end{tabular}

Table 2. Composition of the ilmenites from the sampling sites in the Garimpo Canastrel, Garimpo Wilson, as well as from the kimberlites Douradinho 10 and França 1 (EMP analyses)

\begin{tabular}{l|c|c|c|c|c|c|c|c|c}
\hline $\mathbf{n}^{\mathbf{0}}$ & Sample & $\mathbf{T i O}_{\mathbf{2}}$ & $\mathbf{F e O}$ & $\mathbf{M g O}$ & $\mathbf{M n O}$ & $\mathbf{A l}_{2} \mathbf{O}_{\mathbf{3}}$ & $\mathbf{Z n O}$ & $\mathbf{C r}_{\mathbf{2}} \mathbf{O}_{\mathbf{3}}$ & $\mathbf{T o t a l}$ \\
\hline IC-1 & Conglomerate (Canastrel) & 48.78 & 40.56 & 8.84 & 0.47 & 0.07 & 0.05 & 0.20 & 98.97 \\
\hline IW-1 & Gravel (Wilson) & 50.18 & 37.69 & 9.04 & 0.28 & 0.42 & 0.08 & 0.93 & 98.62 \\
\hline IW-2 & Gravel (Wilson) & 47.39 & 41.52 & 7.58 & 0.30 & 0.02 & 0.98 & 0.05 & 97.84 \\
\hline IK-1 & Kimberlite Douradinho 10 & 52.08 & 32.85 & 12.09 & 0.24 & 0.18 & 0.05 & 1.46 & 98.95 \\
\hline IK-2 & Kimberlite França 1 & 50.18 & 39.74 & 7.44 & 0.47 & 0.04 & 0.22 & 0.05 & 98.14 \\
\hline
\end{tabular}


imbrication of the clasts and cross-bedded sandstones indicate a high energy debris flow. The lateral variation within the conglomerates observed is probably the result of a detachment from its source area. From these features, the authors interpret the depositional environment as alluvial fans and braided channels, a consequence of the uplift of the Alto Paranaíba Arch during Upper Cretaceous time.

That the conglomerates from the Capacete Formation contain kimberlitic indicator minerals in the Coromandel region has been mentioned by many authors (e.g. Barbosa et al. 1970; Barbosa 1991; Sgarbi et al. 1998, 2001; Svisero $\&$ Basei 2005). However, diamond occurrence in these rocks was not recognized in the geological literature until recently. The first mention of the Capacete Formation as a diamond source rock in the Coromandel area has been made by Fernandes (2013) and described and analyzed by Karfunkel et al. (2014) and in this article. The diamonds and garnets from the conglomerate (Capacete Formation) of Garimpo Canastrel indicate a short transport, and therefore, a proximal source for the diamonds.

The results of the field work conducted near Garimpo Wilson and at the headwaters of the Santo Antônio do Bonito River provide no evidence for the occurrence of other kimberlites in the headwater region of the Santo Antônio do Bonito basin, except the known, very small Omega 22 kimberlite, which was abandoned by De Beers (Fig. 4). Magnetic maps support this observation by the lack of clear dipolar anomalies. The authors infer that only the Mata da Corda rocks and Precambrian (sterile) Canastra quartzites and schists are responsible for the deposition of sediments in the alluvium of this river. Therefore, the Capacete Formation rocks, specifically the basal conglomerate, would be the probable source rock of diamonds at the Garimpo Wilson.

The studies of Svisero et al. (2005), Pereira and Fuck (2005), and Andrade (2012) clearly indicate that the Coromandel region garnets vary in composition and belong to the G4 and G5 fields, of eclogitic and pyroxenitic rocks, but some also belong to the lherzolitic G9 field. The classification diagram of garnets (Fig. 6A) exhibits that the garnets from Garimpo Canastrel are of kimberlitic origin and are inserted in the same trend shown by the above authors mentioned. In this study, the ilmenites from the three study areas have been classified as kimberlitic and the data are compared with those from Andrade (2012). They show similar grades of $\mathrm{MgO}$ and $\mathrm{FeO}$, as shown in the diagram of Fig. 6B. These preliminary results compared with literature data characterize the Capacete conglomerate and alluvial gravels as having kimberlitic indicator minerals with similar chemical signatures, indicating that the minerals are derived from mantle xenoliths as a result of the Upper Cretaceous magmatism, as already described by Svisero and Basei (2005).

The detailed mapping and the stratigraphy of the Capacete Formation established by Fernandes (2013) have been essential for determining the stratigraphic positioning of the conglomerates at the Garimpo Canastrel, in which the three diamonds have been recovered. According to geological map, the plateaus composed of Capacete Formation rocks played an important role as watersheds of the Santo Antônio do Bonito, Santo Inácio and Douradinho rivers. Therefore, these rocks represent the main source rocks that provided

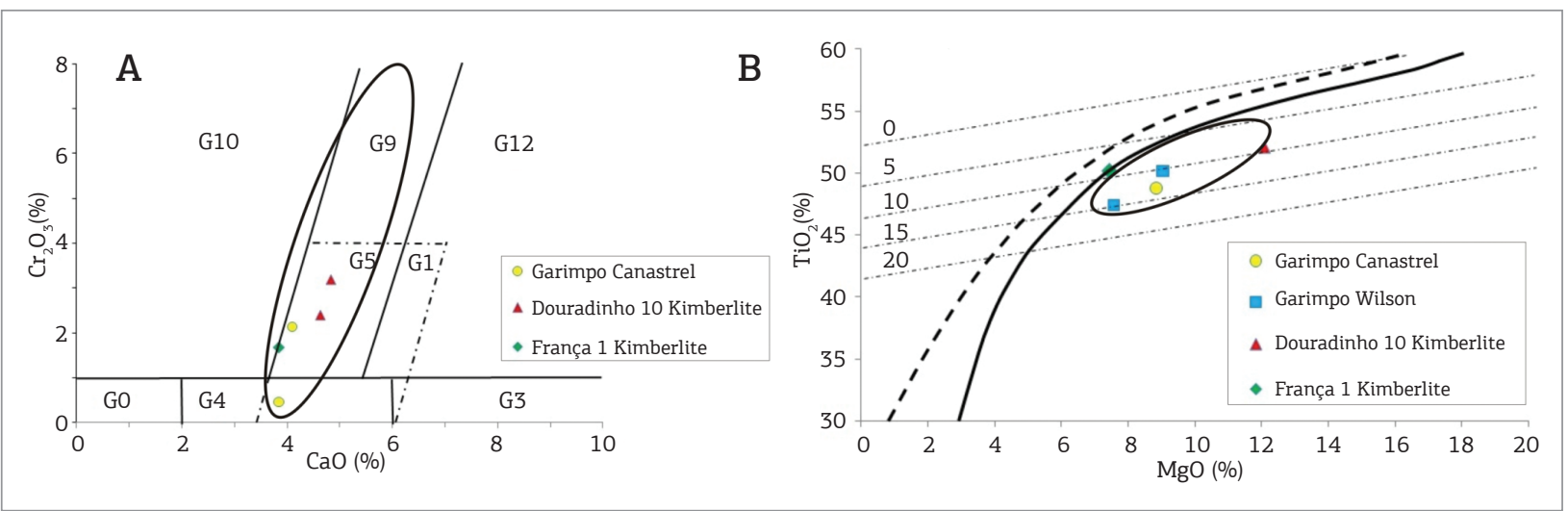

Figure 6. (A) Diagram of $\mathrm{CaOxCr}_{2} \mathrm{O}_{3}$ for garnet classification (after Grütter et al. 2004) showing the garnets analysed in this study. The garnets belong to the G4 and G5 groups, associated with diamonds from eclogitic and peridotitic sources. The ellipsoid represents the trend found by Pereira \& Fuck (2005), Svisero et al. (2005) and Andrade (2012); (B) Diagram of $\mathrm{MgOxTiO}_{2}$ for ilmenite classification (after Wyatt et al. 2004). The solid curve corresponds to the bounding line of kimberlitic ilmenites whereas the dashed curve corresponds to the bounding line of non-kimberlitic ilmenites. The straight, slightly tilted, weaker dashed line represents percentage of $\mathrm{Fe}_{2} \mathrm{O}_{3}$. The ellipsoid corresponds to the trend found by Andrade (2012) from ilmenites of the Douradinho River region. 


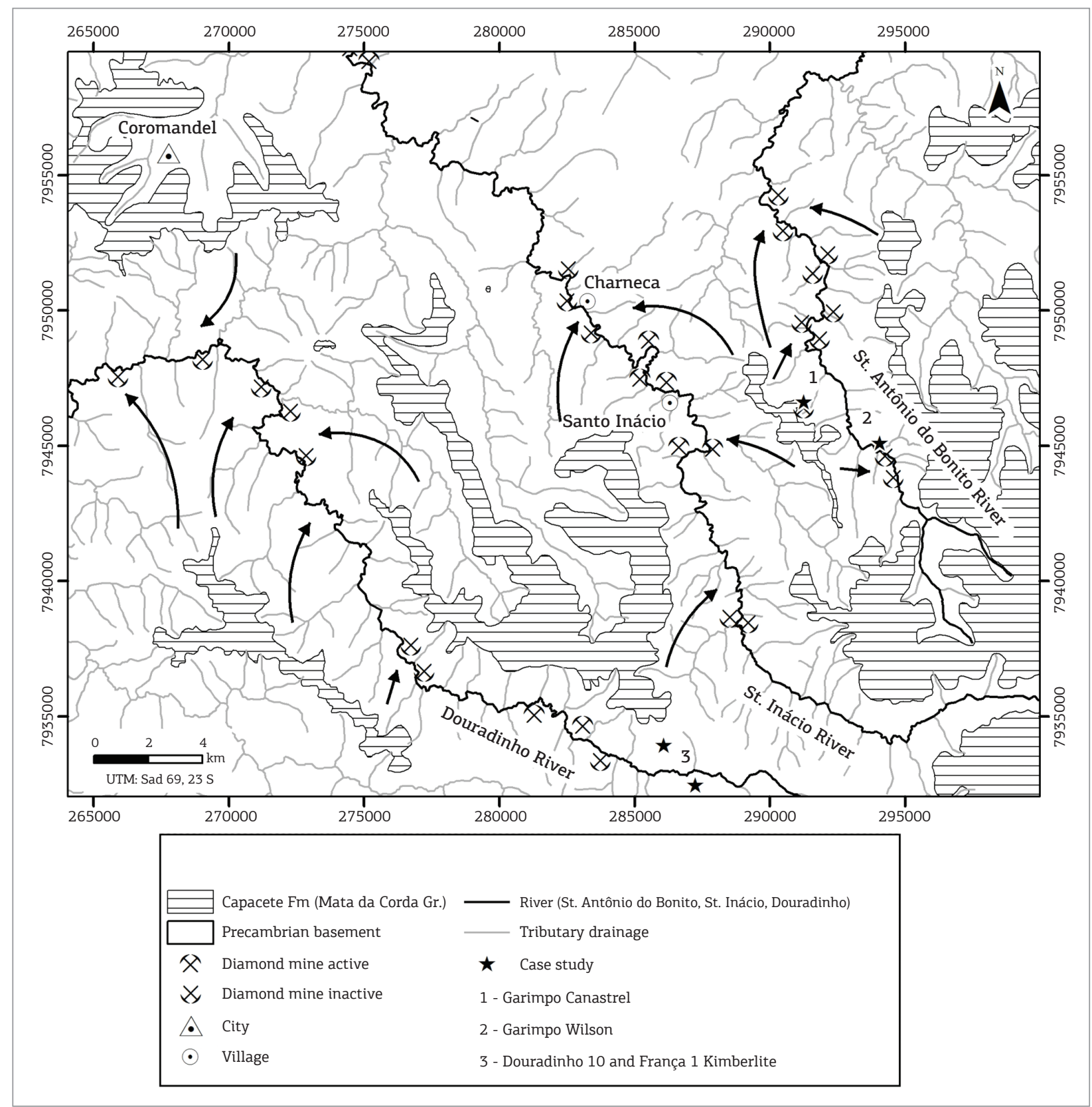

Figure 7. Lithological map of the Capacete Formation and its relation with the distribution of sediments and diamonds in the Santo Antônio do Bonito, Santo Inácio and Douradinho rivers.

the sedimentary detritus, as well as the diamonds to the paleo-alluviums and actual alluviums of these rivers (Fig. 7).

\section{CONCLUSION}

The basal polymictic conglomerates of the Capacete Formation have been shown to be diamondiferous in the Coromandel region. These results also suggest that the conglomerates are probably the main diamond source rock in the Santo Antônio do Bonito, Santo Inácio and Douradinho river alluviums. The authors do not exclude the possibility that neoproterozoic diamictites from Ibiá Group, as well as Cretaceous kimberlites, may have contributed, in other localities, to part of the diamond distribution in the Coromandel region. But in places such as Garimpo Wilson, this contribution can be excluded, since diamictites and kimberlites do not occur upstream from the Garimpo. However, as 
diamonds in the Capacete Formation are scattered over a huge area, the grade appears low and distribution is unknown, therefore they are economically not significant at this time. Future lithostratigraphic and sedimentological studies, especially lateral continuities of the basal Capacete conglomerate, the determination of the conglomerate thickness and diamond content in the Capacete Formation, could result in new investments in diamond extraction from these rocks.

\section{ACKNOWLEDGMENTS}

The authors are grateful to Votorantim Metais for partial financial support, to Prof. Pierre De Brot from CEFET-MG for the SEM images, to kimberlite prospector Osvaldo Soares França for field support, and to the editors and the revisers of $B J G$ for all the fruitful comments and suggestions. AFF thanks the $\mathrm{CNPq}$ for his master's scholarship.

\section{REFERENCES}

Almeida F.F.M. 1967. Origem e evolução da Plataforma Brasileira. Rio de Janeiro, DNPM/DGM, Boletim 241, 36 p.

Almeida F.F.M. 1977. O Cráton do São Francisco. Revista Brasileira de Geociencias, 7(4):349-364.

Andrade K.W. 2012. Química mineral e aspectos geológicos de intrusões kimberlíticas da Província Diamantífera Serra da Canastra (MG): importância na prospecção de intrusões férteis, MS Dissertation, Universidade Federal de Minas Gerais, Belo Horizonte, 153 p.

Barbosa O. 1991. Diamante no Brasil: Histórico, ocorrência, prospecção e lavra. CPRM, Rio de Janeiro, 136 pp.

Barbosa O., Braun O.P.G., Dyer R.C., Cunha C.A.B.R. 1970. Geologia da região do Triângulo Mineiro. Rio de Janeiro, DNPM/DFPM, Boletim 136, 140 p.

Campos J.E.G. \& Dardenne M.A. 1997. Estratigrafia e sedimentação da Bacia Sanfranciscana: uma revisão. Revista Brasileira de Geociencias, 27(3):269-282.

Cas R.A.F. \& Wright J.V. (eds.) 1987. Volcanic Successions: Modern and Ancient. London, Chapman \& Hall, 528 p.

Chaves M.L.S.C., Benitez L., Veiga B.N., Moreira L.A. 2005. Microdiamantes na Bacia do Rio Douradinho (Coromandel, MG): Morfologia primaria e aspectos de dissolução. In: SBG/MG, IV Simpósio Brasileiro de Geologia do Diamante, Diamantina, Boletim 14, p. 39-42.

Dardenne, M.A. 2000. The Brasilia fold belt. In: Cordani U.G., Milani E.G., Thomaz Filho A., Campos D.A. (eds.), Tectonic evolution of South America. 31st International Geological Congress, Rio de Janeiro, Brazil, p. 231-263.

Fernandes A.F. 2013. Tectonoestratigrafia da Faixa Brasília Meridional e estudo de casos de possíveis rochas fonte de diamante, Coromandel-MG, MS Dissertation, Instituto de Geociências, Universidade Federal de Minas Gerais, IGC/UFMG, 119 p.

Gibson S.A., Thompson R.N., Leonardos O.H., Dickin A.P., Mitchell J.G. 1995. The Late Cretaceous impact of the Trindade mantle plume: Evidence from large-volume, mafic, potassic magmatism in SE Brazil. Journal of Petrology, 36(1):189-229.

Gonzaga G.M., Teixeira N.A., Gaspar J.C. 1994. The origin of diamonds in western Minas Gerais, Brazil. Mineralium Deposita, 29:414-421.

Grütter H.S., Gyrney J.J., Menzies A.H., Winter F. 2004. An updated classification scheme for mantle-derived garnet, for use by diamond explorers. Lithos, 77:841-857.

Gurney J.J. 1984. A correlation between garnets and diamonds in kimberlites. In: Glover J.E., Harris P.G. (eds.), Kimberlite Occurrence and Origins: A Basis for Conceptual Models in Exploration. Geology Department and University Extension, University of Western Australia, Publication 8:143-166.
Hasui Y. \& Cordani U.G. 1968. Idades K/Ar de rochas eruptivas mesozoicas do oeste mineiro e sul de Goiás. In: Congresso Brasileiro de Geologia, 22, Belo Horizonte, Anais, p. 139-143.

Hasui Y. \& Haralyi N.L.E. 1991. Aspectos lito-estruturais e geofísicos do Soerguimento do Alto Paranaíba. Geociências, 10:57-77.

Heineck C.A., Vieira V.S., Drumond J.B.V., Leite C.A.L., Lacerda Filho J.V., Valente C.R., Souza J.P., Lopes R.C., Malouf R.F., Oliveira I.W.B., Oliveira C.C., Sachs L.L.B., Paes V.J.C., Junqueira P.A. 2004. Folha SE.23-Belo Horizonte. In: Schobbenhaus C., Gonçalves J.H., Santos J.O.S., Abram M.B., Leão Neto R., Matos G.M.M., Vidotti R.M., Ramos M.A.B., Jesus J.D.A. de. (eds.), Carta Geológica do Brasil ao Milionésimo. CPRM, Brasília, Programa de Geologia do Brasil.

Hoover D.B. \& Karfunkel J. 2009. Large Brazilian diamonds. Australian Gemmologist, 23:434-440.

Karfunkel J. \& Hoppe A. 1988. Late Proterozoic glaciation in Central-Eastern Brazil: Synthesis and model. Palaeogeography, Palaeoclimatology, Palaeoecology, 65:1-21.

Karfunkel J., Hoover D.B., Fernandes A.F., Sgarbi G.N.C., Kambrock K., Oliveira G.D. 2014. Diamonds from the Coromandel area, West Minas Gerais state, Brazil: An update and new data on surface sources and origin. Brazilian Journal Geology (this edition).

Karfunkel J., Martins M.S., Scholz R., McCandless T.E. 2001. Diamonds from the Macaúbas River Basin: Characteristics and possible source. Revista Brasileira de Geociencias, 31:63-78.

King L.C. 1956. A geomorfologia do Brasil Oriental. Revista Brasileira de Geografia, 18:186-263.

Ladeira E.A., Braun O.P.G., Cardoso R.N., Hasui Y. 1971. O cretáceo em Minas Gerais. In: SBG, Congresso Brasileiro de Geologia, 25, São Paulo, Anais, p. 15-31.

Leonardos O.H., Thompson R.N., Fleicher R., Gibson S.A, Svisero D.P., Weska R.H. 1996. Comments on the paper by G.M. Gonzaga et al. The origin of diamonds in western Minas Gerais, Brazil. Mineralium Deposita, 31(4-6):343-344.

Leonardos O.H., Ulbrich M.N., Gaspar J.C. 1991. The Mata da Corda volcanic rocks. In: CPRM, Fifth International Kimberlite Conference, Araxá, Fild Guide Book, p. 655-673 (Special Publication 3/91).

Liccardo A. \& Svisero D.P. 2005. Os grandes diamantes da região de Coromandel (MG) e seu significado geológico. In: IV Simpósio Brasileiro de Geologia do Diamante, Diamantina, Boletim 14, p. 93-96.

Mitchell R.H. 1973. Magnesium ilmenite and its role in kimberlite petrogenesis. Journal of Geology, 81:301-311. 
Pereira L.F., Dardenne M.A., Rosière C.A., Pedrosa-Soares A.C. 1994. Evolução Geológica dos Grupos Canastra e Ibiá na Região entre Coromandel e Guarda-Mor, MG. Geonomos, 2(1):22-32.

Pereira R.S. \& Fuck R.A. 2005. Archean nuclei and distribution of kimberlite and related rocks in the São Francisco Craton, Brazil. Revista Brasileira de Geociencias, 35(3):93-104.

Reis E. 1959. Os grandes diamantes brasileiros. Rio de Janeiro. DNPM/DGM, Boletim 191, 65 p.

Rodrigues J.B. 2008. Proveniência sedimentar dos grupos Canastra, Ibiá, Vazante e Bambuí - Um Estudo de zircões detríticos e Idades Modelo Sm-Nd, PhD Thesis, Instituto de Geociências, Universidade de Brasília, Brasília, 128 p.

Schmid R. 1981. Descriptive nomenclature and classification of pyroclastic deposits and fragments: Recommendations of the IUGS Subcommission on the Systematics of Igneous Rocks. Geology, 9:41-43.

Seer H.J., Brod J.A., Fuck R.A., Pimentel M.M., Boaventura G.R., Dardenne M.A. 2001. Grupo Araxá em sua área tipo, um fragmento de crosta oceânica Neoproterozóica na Faixa de Dobramentos Brasília. Revista Brasileira de Geociencias, 31:385-396.

Seer H.J. \& Dardenne M.A. 2000. Tectonostratigraphic Terrane analysis on Neoproterozoic times: The case study of Araxá sinform, Minas Gerais state, Brazil: Implications to the final collage of the Gondwanaland. Revista Brasileira de Geociencias, 30(1):78-81.

Sgarbi P.B.A. 1991. Petrografia e Geoquímica das Rochas do Grupo Mata da Corda na Região de Carmo do Paranaíba, MG. Dissertação de Mestrado, UFRJ, $214 \mathrm{p}$.

Sgarbi P.B.A., Gaspar J.C., Valença J.G. 2000. Brazilian kamafugites. Revista Brasileira de Geociencias, 30(3):417-420

Sgarbi G.N.C., Sgarbi P.B.A., Brito W. 1998. Conglomerados cretáceos e suas relações com o vulcanismo alcalino no oeste mineiro. In: SBG, Congresso Brasileiro de Geologia, 40, Belo Horizonte, Anais, p. 97.

Sgarbi G.N.C., Sgarbi P.B.A., Campos J.E.G., Dardenne M.A., Penha U.C. 2001. Bacia Sanfranciscana: O registro fanerozóico da Bacia do São Francisco. In: Pinto C.P., Martins-Neto M.A. (eds.), Bacia do São Francisco. Geologia e Recursos Minerais. Belo Horizonte. SBG/MG. p. 93-138.
Sgarbi P.B.A, Heaman L.M., Gaspar J.C. 2004. U-Pb perovskite ages for Brazilian kamafugitic rocks: Further support for a temporal link a mantle plume hotspot track. Journal of South American Earth Sciences, 16:715-724.

Svisero D.P. 1992. Origem do diamante no Brasil: Uma análise à luz dos conhecimentos atuais. In: SBG, Congresso Brasileiro de Geologia, 37, São Paulo, Anais, p. 117-119.

Svisero D.P. \& Basei M.A.S. 2005. Novas evidências de uma origem proximal para o diamante da região de Coromandel, Minas Gerais. In: SBG/MG, Anais IV Simpósio Brasileiro de Geologia do Diamante, Diamantina, Boletim 14, p. 166-168.

Svisero D.P., Haralyi N.L.E., Cretelli C.A. 1986. Geologia dos kimberlitos Vargem 1 e Vargem 2, Coromandel, Minas Gerais. In: Congresso Brasileiro de Geologia, 34, Goiânia, Anais, vol. 4, p. 1671-1685.

Svisero D.P., Meyer H.O.A., Haralyi N.L.E., Hasui Y. 1984. A note on the geology of some Brazilian kimberlites. Journal of Geology, 92(3):331-338.

Svisero D.P., Ulbrich M.N.C., Vlach S.R.F. 2005. Composição, origem e significado de minerais resistatos de intrusões kimberlíticas da região de Coromandel, Minas Gerais. In: SBG/MG, Anais IV Simpósio Brasileiro de Geologia do Diamante, Diamantina, Bol. 14, 169-172.

Tompkins L.A. \& Gonzaga G.M. 1989. Diamonds in Brazil and a proposed model for the origin and distribution of diamonds in the Coromandel Region, Minas Gerais, Brazil. Economic Geology, 84:591-602

Valeriano C.M., Machado N., Simonetti A., Valladares C.S., Seer H.J., Simões L.S.A. 2004. U-Pb geochronology of the southern Brasilia belt (SE-Brazil): Sedimentary provenance, Neoproterozoic orogeny and assembly of West Gondwana. Precambrian Research, 130(1-4):27-55.

Wyatt B.A., Baumgartner M., Anckar E., Grutter H. 2004. Compositional classification of "kimberlitic" and "non-kimberlitic" ilmenite. Lithos, 77:819-840.

Arquivo digital disponível on-line no site www.sbgeo.org.br 